\section{Veinte años de Cátedra Blanca}

$1999-2019$

1, 2. Seminario en la Tourette. Noviembre 2001

. 5. Visita a canter de peanra de Máés con Francisco Cifuentes. Feb

6. Jury Proyectos ETSAB, Antonio Cruz. Septiembre 1999

8. Sesión de corrección de maquetas
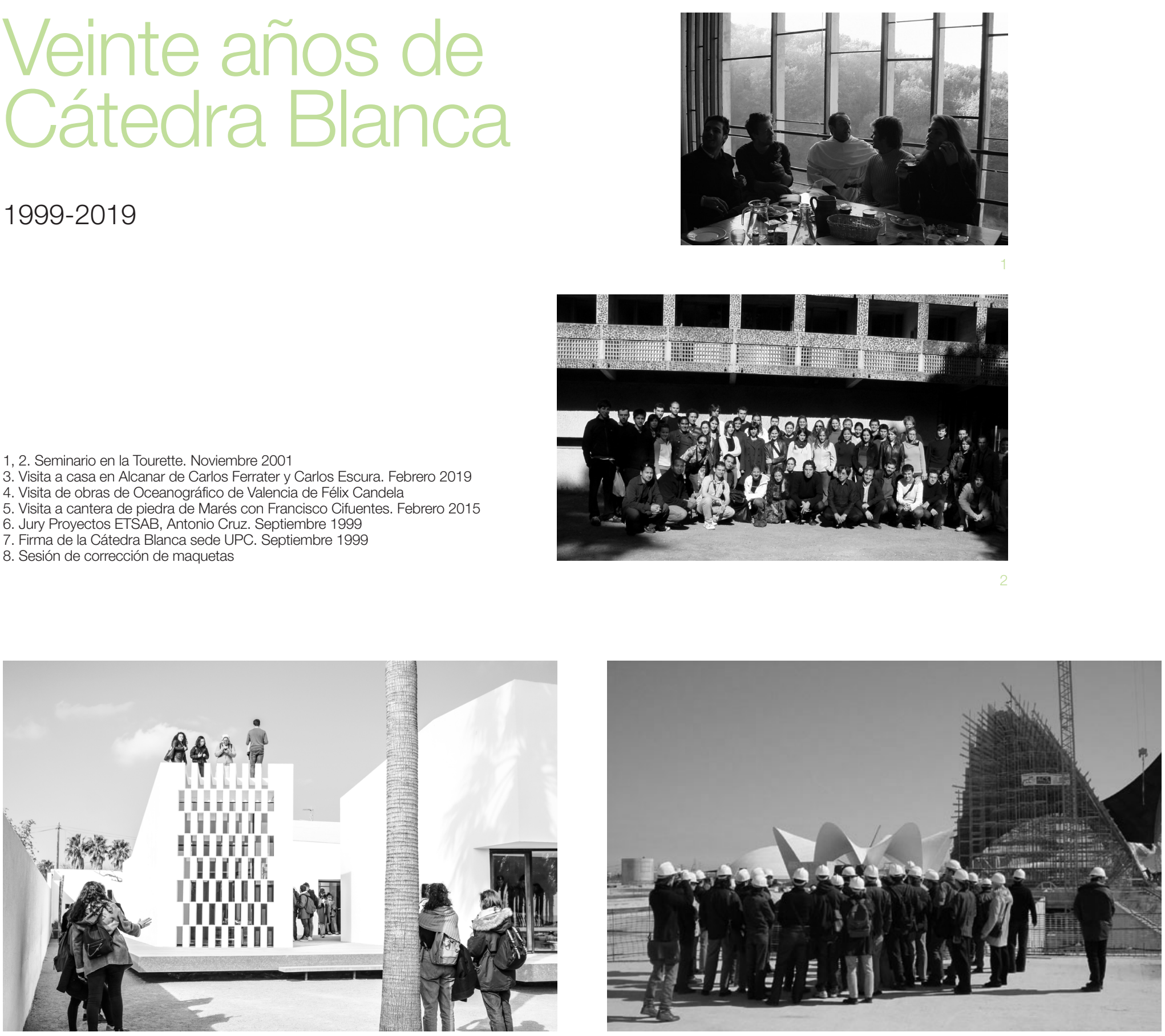
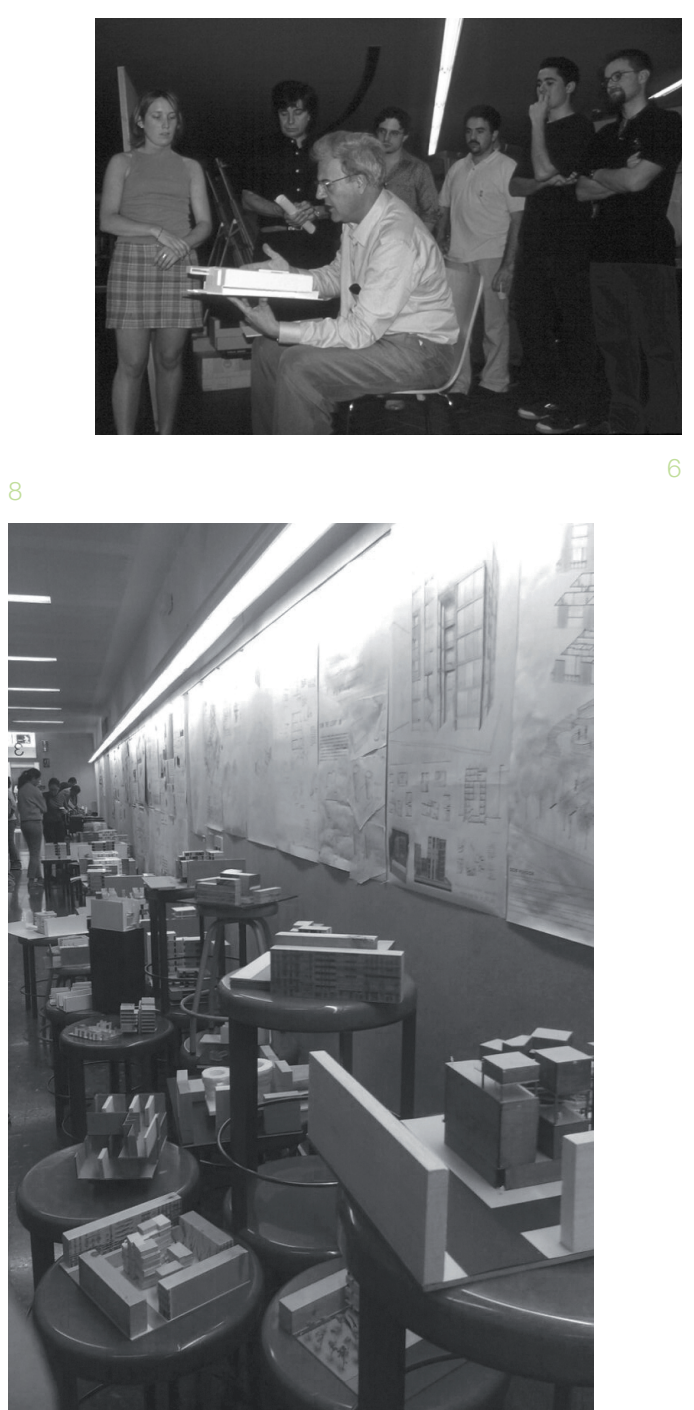